\title{
Rancang Bangun Sistem Informasi Rekam Medik Studi Kasus: UPTD Puskesmas Padamara Kabupaten Purbalingga
}

\author{
Eka Rahmawati ${ }^{1}$, Saifudin $^{2}$, Chandra Kesuma ${ }^{3}$, Amin Nur Rais ${ }^{4}$ \\ ${ }^{1}$ Prodi Sistem Informasi Kampus Kota Surakarta, Universitas Bina Sarana Informatika \\ 2,3Prodi Teknologi Komputer Kampus Kabupaten Banyumas, Universitas Bina Sarana \\ Informatika \\ ${ }^{4}$ Prodi Sistem Informasi Akuntansi, Universitas Bina Sarana Informatika

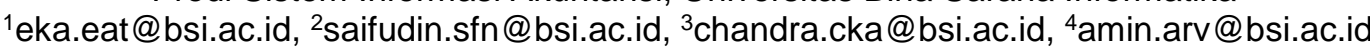

\begin{abstract}
Computer is the one of technology that can make people activity easier. To maximize the computer utilization it need a computerization system. Like on UPTD Puskesmas Padamara that give health service. The service that given are outpatient, inpatient and emergency unit. Until now, medical records procedure at UPTD Puskesmas Padamara still done by hand, one of them is on outpatient procedure. The filing of medical patient data was recorded on paper that susceptible to damage and data loss. Besides that, the history of medical patient start form anamnesis, diagnose and therapy wrote on paper too. The Medical patient checkup data of inpatient still on the document. The data have done randomly archived, so it needs a long time for seeking for data and manage the report. As a health unit that serves the worldwide community, UPTD Puskesmas Padamara needs an information system that can accelerate performance and increase redundancy, data loss, and data detriment. The information system also can make archived and data searched easily and can block access from uncompetent people. Therefore, it's necessary to make medical records information system on UPTD Puskesmas Padamara. A computerization system besides accelerate performance also can make data reporting easier.
\end{abstract}

Keywords: Medical Records Information System, Medical Records

Abstrak: Komputer merupakan salah satu teknologi yang dapat mempermudah aktivitas manusia. Agar dapat memaksimalkan penggunaan komputer maka perlu dibuat sebuah sistem yang terkomputerisasi. Begitupun pada UPTD Puskesmas Padamara yang memberikan pelayanan kesehatan. Pelayanan yang diberikan meliputi rawat jalan, rawat inap dan UGD. Sampai saat ini prosedur rekam medik pada UPTD Puskesmas Padamara masih dilakukan dengan manual salah satunya pada prosedur pendaftaran rawat jalan. Data pasien yang akan melakukan pendaftaran dicatat dalam sebuah dokumen yang rentan terhadap kerusakan atau hilangnya data. Selain itu riwayat pasien mulai dari diagnosa, anamnesia, dan terapi juga dicatat dalam dokumen. Pencatatan data pemeriksaan pasien rawat inap masih dilakukan dalam lembaran kertas. Data diarsipkan secara tidak terstruktur, sehingga akan membutuhkan waktu lama ketika melakukan pencarian data dan membuat laporan. Tempat arsip yang tidak dijaga dengan ketat sehingga terdapat kemungkinan pihak yang tidak berwenang mengakses data. Sebagai unit kesehatan yang melayani masyarakat umum, UPTD Puskesmas Padamara membutuhkan sebuah sistem informasi yang dapat mempercepat kinerja dan mengurangi redudansi, hilangnya data dan kerusakan data. Sistem informasi juga dapat mempermudah pengarsipan dan pencarian data serta dapat menghalangi pengaksesan data oleh pihak yang tidak berwenang. Oleh karenanya perlu dibuat sistem informasi rekam medik pada UPTD Puskesmas Padamara. Sistem informasi akan membantu setiap prosesnya dapat berjalan dengan baik dan terstruktur.

Kata kunci: Perancangan Sistem Informasi, Sistem Informasi Rekam Medik 
This is an open access article distributed under the Creative Commons Attribution License, which permits unrestricted use, distribution, and reproduction in any medium, provided the original work is properly cited. (O2019 by author and IJSE-Indonesian Journal on Software Engineering.

\section{A. PENDAhUluan}

Kesehatan merupakan faktor penting dalam kehidupan manusia. Kondisi sakit dapat mengganggu aktivitas sehari-hari. Kesehatan yang sangat penting bagi manusia mendorong dibuatnya layanan kesehatan yang bergerak sebagai fasilitas publik. Penyedia layanan kesehatan tersebut dapat didirikan oleh pemerintah, swasta maupun perorangan seperti rumah sakit, puskesmas dan klinik kesehatan. Semakin sadarnya masyarakat akan kesehatan maka semakin banyak pula pembangunan fasilitas pelayanan kesehatan. Agar standar pelayanan setiap fasilitas kesehatan memiliki kesetaraan, maka pemerintah pun membuat standar tersendiri untuk sebuah tempat pelayanan kesehatan yang diatur dalam Peraturan Menteri Kesehatan.

Pesatnya perkembangan teknologi membuat aktifitas manusia dapat dilakukan dengan mudah dan dengan waktu yang singkat. Salah satu teknologi yang membantu aktifitas manusia ialah komputer. Kata komputer merupakan adaptasi dari bahasa Latin computere yang memiliki arti menghitung atau dalam bahasa Inggris to compute. Sanders menyampaikan dalam (Sutarman, 2009) komputer merupakan sebuah sistem yang berbasis elektronik untuk manipulasi data dengan cepat dan tepat serta dirancang agar secara otomatis menerima dan menyimpan data input, memprosesnya, dan menghasilkan output dengan suatu langkahlangkah intstruksi program yang tersimpan pada memori (stored program). Fuori menyampaikan dalam (Sutarman, 2009) komputer merupakan tools yang digunakan sebagai data processor yang melakukan perhitungan dalam jumlah besar dan cepat, baik aritmatika yang besar atau operasi logika, dengan proses yang dilakukan tanpa adanya campur tangan manusia. Dengan definisi komputer diatas maka dapat disimpulkan bahwa komputer dapat mempermudah aktifitas manusia.

Dengan adanya komputer maka memicu pula sistem terkomputerisasi. Sistem adalah rangkaian aktifitas yang dilakukan untuk mencapai tujuan tertentu. Menurut (Sutarman, 2009) sistem merupakan elemen-elemen yang saling terkait dan melakukan interaksi pada satu kesatuan dalam rangka mencapai tujuan utama. Sedangkan sistem terkomputerisasi merupakan sebuah sistem yang melibatkan teknologi dalam pencapaian tujuan sehingga sebuah aktifitas dapat dilaksanakan dengan efektif.

Namun demikian, tidak semua aspek dapat mengikuti dengan cepat perkembangan teknologi. Masih banyak instansi yang di bidang pelayanan kesehatan masyarakat yang belum menggunakan sistem informasi untuk mendokumentasikan setiap transaksi yang dilakukan. Seperti pada Unit Pengelola Teknis Daerah (UPTD) Puskesmas Padamara yang merupakan tempat pelayanan kesehatan masyarakat. Pencatatan dilakukan secara manual sehingga membutuhkan waktu lama. Belum lagi jika terjadi kesalahan pencatatan akibat human error. Oleh karenanya perlu dibuat sebuah sistem terkomputerisasi yang dapat meningkatkan kinerja dan menghemat waktu serta biaya.

\section{B. TINJAUAN PUSTAKA}

\section{Program}

Menurut (Sutarman, 2009) program adalah barisan perintah/instruksi yang disusun sehingga dapat dipahami oleh komputer dan kemudian dijalankan sebagai barisan perhitungan numerik, di mana barisan perintah tersebut berhingga, berakhir, dan menghasilkan output. Dalam merancang sebuah program dibutuhkan standar aktifitas atau proses, diantaranya:

a. Analisa Kebutuhan

Dalam merancang suatu program, terlebih dahulu dilakukan analisa kebutuhan. Analisa kebutuhan menyangkut apa saja yang dibutuhkan dalam input data, proses dan output.

b. Desain

Setelah melakukan analisa kebutuhan, tahap selanjutnya yaitu desain. Desain dilakukan untuk menghasilkan antar muka yang sesuai dengan analisa kebutuhan.

c. Koding Merupakan sebuah tahapan dimana bahasa pemrograman diimplementasikan ke dalam desain yang sudah dibuat. 
d. Pengujian

Merupakan tahap untuk mengetahui apakah program yang sudah dibuat sesuai dengan apa yang diharapkan atau tidak.

\section{Bahasa Pemrograman}

Merupakan salah satu faktor utama dalam proses berdirinya suatu program. Menurut (Kurniadi, 2008) bahasa pemrograman adalah perintah-perintah atau instruksi yang dimengerti oleh komputer untuk melakukan tugas-tugas tertentu. Jenis-jenis bahasa pemrograman ada 2 yaitu:

a. Bahasa Tingkat Rendah

Dirancang agar setiap instruksi langsung dikerjakan oleh komputer tanpa translator. Contoh : Assembler.

b. Bahasa Tingkat Tinggi

Merupakan bahasa pemrograman yang dalam penulisan pernyataannya mudah dipahami secara langsung. Bahasa pemrograman ini perlu diterjemahkan oleh translator bahasa.

Bahasa pemrograman memiliki beberapa kriteria diantaranya:

a. Clarity, simplicity dan unity

Merupakan suatu kombinasi yang membantu programmer mengembangkan suatu algoritma.

b. Orthogonality

Merupakan suatu atribut yang dapat dikombinasikan dengan beragam fitur bahasa permrograman sehingga setiap kombinasinya mempunyai arti dan dapat digunakan.

c. Kewajaran untuk Aplikasi

Maksud dari kewajaran disini adalah aplikasi terdiri dari struktur data, operasi-operasi, struktur kontrol dan sintaks yang tepat untuk memecahkan suatu masalah.

d. Mendukung Abstraksi

Dukungan diberikan kepada suatu hal yang substansial bagi programer untuk membuat suatu solusi dari masalah yang dihadapi.

e. Kemudahan untuk Verifikasi Program

Suatu program akan dengan mudah dibangun dan dikembangkan dengan verifikasi data yang sederhana.

f. Lingkungan Pemrograman

Dalam hal ini editor yang digunakan, dokumentasi yang baik, fasilitas debugging, user interface yang baik ataupun tools lain yang dapat digunakan untuk memudahkan pekerjaan komputer.

g. Probabilitas Program

Kemudahan program untuk dipakai di berbagai jenis komputer.

h. Biaya Penggunaan

Biaya penggunaan meliputi biaya eksekusi program, biaya kompilasi program, biaya penciptaan, testing dan penggunaan program serta biaya pemeliharaan program.

\section{Basis Data}

Dalam (Fathansyah, 2007) disebutkan bahwa basisdata terdiri dari 2 kata yaitu basis dan data. Basis dapat diartikan sebagai gudang atau markas yang menjadi tempat bersarang/berkumpul. Data merupakan representasi fakta dunia nyata yang mewakili suatu objek seperti manusia (pegawai, siswa, pembeli, pelanggan), barang, hewan, peristiwa, konsep, keadaan, dan sebagainya yang direkam dalam bentuk angka, huruf, simbol, teks, gambar, bunyi atau kombinasinya.

Sebuah basis data terdiri dari sekumpulan tabel yang digunakan untuk penyimpanan data. Menurut (Simarmata, 2008) basis data adalah koleksi data yang bisa mencari secara menyeluruh dan secara sistematis memelihara dan me-retrieve informasi. Menurut (Priyadi, 2014) pengertian basis data adalah sekumpulan fakta berupa representasi tabel yang saling berhubungan dan disimpan dalam media penyimpanan digital. Elemen dalam basis data terdiri dari tabel, field key, (primary dan foreign key), field non key, record dan kardinalitas.

a. Tabel

Menurut (Priyadi, 2014) tabel direpresentasikan menjadi suatu bentuk segiempat berupa matriks, yang terdiri dari kolom dan baris. Lokasi pertemuan antara kolom dan baris 
tersebut memiliki suatu nilai tertentu. Tabel merupakan sebuah elemen basis data yang terdiri dari baris (record) dan kolom (field).

b. Field

Field atau atribut merupakan sebuah anggota dari suatu entitas yang digunakan untuk menampung record.

c. Record

Record merupakan elemen-elemen dengan tipe data yang bervariasi namun saling berkaitan. Record menginformasikan tentang suatu entitas secara lengkap.

d. Kardinalitas

Kardinalitas merupakan batasan dari banyaknya hubungan yang dapat dilakukan oleh suatu himpunan entitas dalam melakukan relasi dengan himpunan entitas lainnya. Variasi kemungkinan untuk melakukan relasi yang dimiliki oleh kardinalitas terdiri dari empat macam, yaitu Kardinalitas satu ke satu (1:1), Kardinalitas satu ke banyak (1:N), Kardinalitas banyak ke satu (N:1) dan Kardinalitas banyak ke banyak (N:N) (Priyadi, 2014).

Dalam merancang basis data, perlu diperhatikan prinsip-prinsip perancangan basis data. Prinsip perancangan basis data terdiri dari:

a. Redudansi

Merupakan sebuah keadaan dimana data melebihi ukuran data dan dapat mendorong ke arah yang tidak normal.

b. Bentuk Normal

Merupakan basis data yang sudah tidak terdapat redudansi di dalamnya.

c. Normalisasi

Merupakan proses perubahan perancangan basis data yang membuat basis data dalam bentuk normal.

\section{Model Pengembangan Perangkat Lunak}

Model pengembangan perangkat lunak merupakan sebuah metode untuk mengembangkan dan mengimplementasikan perangkat lunak menggunakan suatu metodologi pengembangan perangkat lunak. Software development live cycle (SDLC) adalah proses membangun atau memperbaiki suatu sistem perangkat lunak dengan menerapkan metodologi dan model yang digunakan untuk mengembangkan sistem perangkat lunak sebelumnya dengan cara yang sudah teruji baik(S \& Shalahuddin, 2004). Metodologi yang digunakan dalam rancang bangun program rekam medik ini adalah Waterfall. Berikut gambar model air terjun:

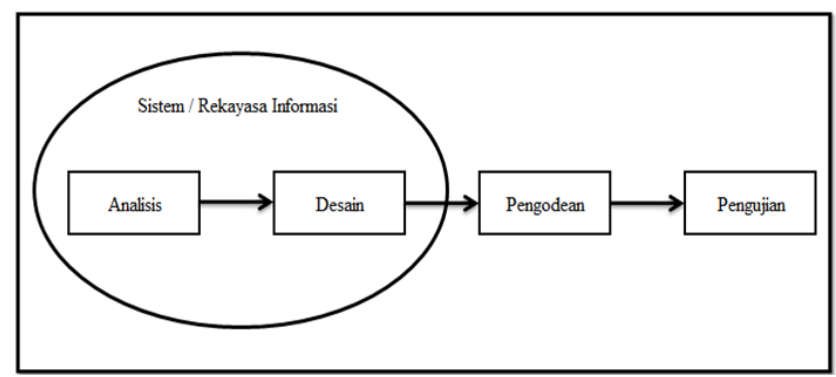

Sumber: (S \& Shalahuddin, 2004)

Gambar 1. Model Air Terjun

Model waterfall menyediakan pendekatan alur hidup perangkat lunak secara sequential atau terurut dimulai dari analisa, desain, pengkodean, pengujian dan tahap pendukung.

\section{Definisi Sistem Informasi}

Menurut (Nuraida \& S.E., 2008) Sistem merupakan kumpulan dari komponen dimana setiap komponen mempunyai fungsi yang saling berinteraksi dan saling tergantung serta memiliki satu kesatuan yang utuh untuk bekerja mencapai tujuan tertentu. Informasi merupakan kumpulan dari data. Untuk mengembangkan sistem, perlu membedakan unsur-unsur dari sistem yang membentuknya. Dalam (Fatta, 2007) disebutkan karakteristik sistem yang dapat membedakan satu sistem dengan sistem lainnya, diantaranya:

a. Batasan (boundary)

b. Lingkungan (environment) 
c. Masukan (input)

d. Keluaran (output)

Menurut Komaruddin dalam (Nuraida \& S.E., 2008) sistem informasi merupakan seperangkat prosedur yang terorganisasi dengan sistematik yang jika dilaksanakan akan menyediakan informasi yang dapat dimanfaatkan dalam proses pembuatan keputusan. Menurut Laitch dan Bavis dalam (Kusrini, 2010) sistem informasi merupakan sebuah sistem di dalam organisasi yang menjadi titik temu dari kebutuhan pengolahan transaksi harian, mendukung operasi, bersifat manajerial dan kegiatan strategi dari suatu organisasi dan menyediakan pihak luar tertentu dengan laporan-laporan yang diperlukan.

Jadi pada dasarnya sistem informasi adalah suatu tahapan atau proses untuk mendapatkan suatu informasi yang dapat dimanfaatkan sesuai dengan kebutuhan.

\section{Komponen Sistem Informasi}

Dalam suatu sistem informasi terdapat komponen-komponen sistem informasi. Dalam kusrini (2010:9) komponen sistem informasi terdiri dari:

a. Perangkat keras (hardware)

b. Perangkat lunak (software)

c. Prosedur

d. Orang

e. Basis data (database)

f. Jaringan komputer dan komunikasi data

\section{Rekam Medis}

Berdasarkan peraturan menteri kesehatan tentang rekam medis (Indonesia, n.d.) yang dimaksud dengan rekam medis adalah dokumen tentang identitas pasien, pemeriksaan, pengobatan, tindakan dan pelayanan lain yang telah diberikan kepada pasien. Pasien merupakan orang yang melakukan pemeriksaan atau konsultasi tentang kesehatan yang dimiliki untuk memperoleh pelayanan kesehatan yang diperlukan. Proses tersebut dapat dilkaukan secara langsung maupun tidak langsung kepada dokter atau dokter gigi.

\section{Entity Relationship Diagram (ERD)}

ERD merupakan diagram yang digunakan untuk permodelan basis data yang komponennya terdiri dari simbol entitas, relasi, atribut dan garis penghubung. Komponen ERDiagram terdiri dari:
a. Entitas
Merupakan notasi untuk mewakili suatu objek dengan karakteristik sama yang dilengkapi oleh atribut namun setiap objek akan berbeda dengan objek lainnya. Objek tersebut dapat berupa benda, pekerjaan, orang dan tempat.
b. Relasi fakta.
Merupakan notasi yang digunakan untuk menghubungkan beberapa entitas berdasarkan
c. Atribut
Merupakan notasi yang menjelaskan karakteristik suatu entitas dan juga relasinya. Atribut dapat berupa key ataupun foreign key.
d. Garis Penghubung
Merupakan garis yang menggambarkan relasi atau keterkaitan antara komponen didalam diagram ERD.

Kunci merupakan sebuah kombinasi dari satu kolom atau lebih yang berada didalam suatu tabel yang secara unik mendefinisikan baris dalam tabel. Menurut Simarmata (2007:162) ada empat sifat yang diinginkan pada kunci :
a. Familiarity
b. Stability
c. Minimality
d. Simpicity 


\section{Pengkodean}

Pengkodean dilakukan untuk mengklasifikasikan data yang dimasukkan kedalam komputer untuk mengambil berbagai informasi. Menurut (Kusrini, 2010)kode akun adalah pemberian tanda/nomor tertentu dengan memakai angka, huruf, atau kombinasi angka dan huruf pada setiap akun atau rekening. Berikut sifat-sifat kode akun sebagai berikut:

a. Mudah diingat,

b. Sederhana dan singkat,

c. Konsisten,

d. Memungkinkan adanya perubahan akun baru tanpa mengubah kode akun yang sudah ada.

\section{Hierarchy Input Process Output (HIPO)}

HIPO adalah alat dokumentasi program yang biasanya dimanfaatkan dalam metode pengembangan suatu perangkat lunak. Sekarng, tool ini juga dimanfaatkan sebagai alat desain dan teknik dokumentasi. Tools menjadi salah satu yang paling tepat untuk menggabarkan siklus pengembangan sistem yang berbasis pada fungsi, yaitu tiap-tiap modul di dalam sistem digambarkan oleh fungsi utamanya. Menurut (Fatta, 2007) HIPO merupakan teknik untuk mendokumentasikan pengembangan suatu sistem yang dikembangkan oleh IBM.

HIPO dapat digunakan sebagai alat pengembangan sistem dan teknik dokumentasi program. Penggunaannya mempunyai beberapa sasaran, yaitu:

a. Untuk menyediakan suatu struktur guna memahami fungsi-fungsi dari sistem.

b. Untuk lebih menekankan fungsi-fungsi yang harus diselesaikan oleh program.

c. Untuk menyediakan penjelasan yang jelas dari input yang harus digunakan dan output yang harus dihasilkan oleh masing-masing fungsi pada tiap-tiap tingkatan dari program HIPO.

d. Untuk menyediakan output yang tepat dan sesuai dengan kebutuhan-kebutuhan pemakai.

\section{Diagram Alir Program (Flowchart)}

Merupakan alat yang digunakan untuk menggambarkan sebuah algoritma. Flowchart merupakan alur pemikiran yang dituangkan ke dalam bentuk gambar/simbol. Menurut (Suarga, 2012) Flowchart adalah rangkaian simbol gambar (chart) yang menggambarkan aliran (flow) dari proses suatu data. Pemanfaatan flowchart (diagram alir) membuat programmer mampu menjelaskan idenya secara tertulis agar rancangan program dapat dipahami oleh orang lain, klien, atau tim work.

\section{MySQL}

MySQL tergolong sebagai Database Management System (DBMS) yang beguna untuk mengelola data. MySQL banyak digunakan untuk kepentingan database dikarenakan bersifat open source. Cara mengakses database MySQL adalah menggunakan phpMyAdmin. Aplikasi ini dapat dijalankan melalui web browser apa saja. Di dalam suatu database terdapat beberapa tabel yang tersusun dengan melibatkan sejumlah field. Dalam merancang field, perlu ditentukan tipe data yang ditentukan berdasarkan maksud tertentu.

\section{Microsoft Visual Basic 6.0}

Aplikasi yang digunakan dalam merancang program rekam medik adalah Microsoft Visual Basic 6.0. Visual Basic merupakan bahasa pemrograman komputer yang sudah tidak asing lagi dikalangan proggrammer. Visual Basic merupakan salah satu bahasa yang banyak dipelajari dan menghasilkan program-program aplikasi berbasis windows. Visual Basic adalah perkembangan dari Beginner's All-Purpose Symbolic Instruction Code (BASIC) yang mulai dirancang pada tahun 1950. Sedangkan untuk Visual Basic sendiri mulai dikembangkan pada tahun 80-an. Microsoft Visual Basic merupakan bahasa pemrograman yang memberikan penawaran terhadap Integrated Development Environment (IDE) visual untuk membuat program perangkat lunak menggunakan sistem operasi Microsoft Windows dengan model program (COM) (Winarno, Ali, \& SmittDev Community, 2013).

Menurut (Kurniadi, 2008) Visual Basic 6 memiliki beberapa versi yang ada dipasaran diantaranya adalah :

a. Standard Edition/Learning Edition : ini adalah versi standar yang sudah mencakup berbagai sarana dasar dari Visual Basic 6 untuk mengembangkan aplikasi. 
b. Professional Edition : versi ini memberikan berbagai sarana ekstra yang dibutuhkan oleh para programmer profesional. Misalnya seperti kontrol-kontrol tambahan, dukungan untuk pemrograman internet, compiler untuk membat file Help, serta sarana pengembangan database yang lebih baik.

c. Entrerprise Edition : versi ini dikhususkan untuk para programmer yang ini mengembangkan aplikasi remote computing atau client/server. Biasanya versi ini digunakan untuk membuat aplikasi pada jaringan.

\section{Crystal Reports 8.5}

Crystal Reports merupakan sebuah program khusus untuk membuat laporan yang terpisah dengan Visual Basic. Crystal Report merupakan program yang terpisah dengan program Microsoft Visual Basic 6.0, tetapi keduanya dapat dihubungkan (Linkage) (Madcoms, 2010). Versi yang digunakan dalam penyusunan laporan dalam program rekam medik pada UPTD Puskesmas Padamara adalah Crystal Reports 8.5.

\section{B METODE PENELITIAN}

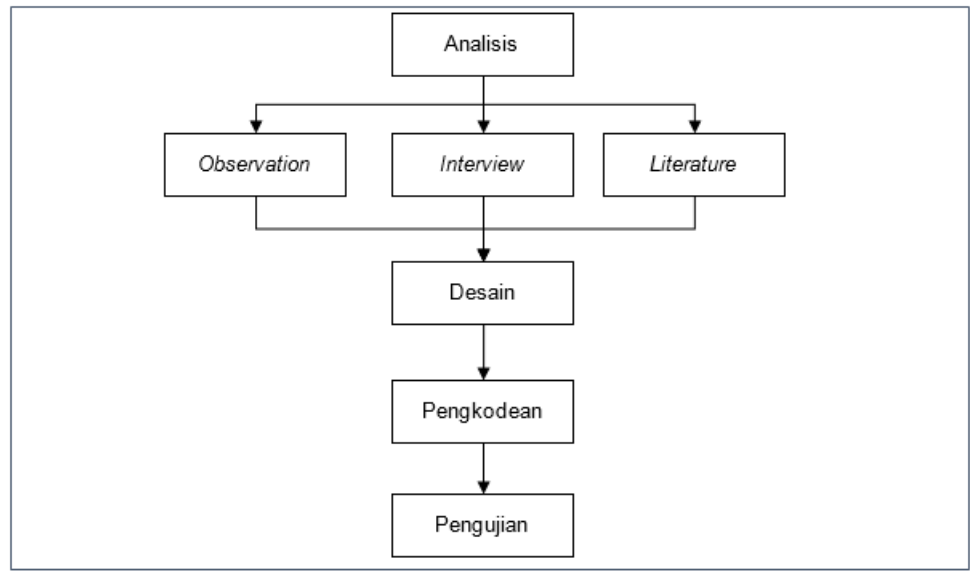

Gambar 2. Metode Penelitian

\section{HASIL DAN PEMBAHASAN}

Penggunaan sistem terkomputerisasi pada sebuah instansi bertujuan untuk mempermudah proses pengolahan data. Pelayanan kesehatan di Puskesmas Padamara, pengolahan data masih dilakukan secara manual diantaranya:

1. Pencatatan rekap pendaftaran pasien rawat jalan dan rawat inap, pembayaran rawat inap umum, serta pembuatan laporan masih dicatat dalam lembaran kertas dan di input ke Microsoft Excel. Hal ini memungkinkan kerusakan atau hilangnya data.

2. Pencatatan yang dilakukan secara manual juga lebih rentan terhadap kesalahan dan waktu yang dibutuhkan untuk proses pencatatan lebih lama.

3. Pengarsipan data rekam medik masih acak sehingga akan mengalami kesulitan untuk menemukan data dalam waktu singkat.

Program Rekam Medik dibuat menggunakan Visual Basic 6.0. dengan analisa kebutuhan perangkat lunak sebagai berikut :

1. Kebutuhan Antar Muka

Kebutuhan untuk pengembangan perangkat lunak program rekam medik adalah:

a. Perangkat lunak harus mampu membaca data kunci yang dimasukkan dalam pencarian data, proses pemasukan data, perubahan data dan pemasukkan data.

b. Perangkat lunak yang dibangun mempunyai tampilan yang familiar bagi pengguna perangkat lunak.

c. Perangkat lunak mampu menyimpan data yang dimasukkan oleh pengguna ke penyimpanan (storage).

2. Kebutuhan Data Mampu memperbarui data yang tersimpan dalam storage.

Data yang diolah pada sistem informasi rekam medik adalah:

a. Data master 
Terdiri dari data pasien, data dokter, data perawat, data staf, data bidan, data laboran, data obat, data disposable, data pelayanan, data poli dan data rumah sakit.

b. Data transaksi

Terdiri dari transaksi pendaftaran, rawat jalan, rawat inap masuk, rawat inap keluar \& pembayaran, pemeriksaan rawat inap dan ugd.

3. Kebutuhan Fungsional

Fungsi yang dimiliki oleh sistem informasi rekam medik diantaranya:

a. Mengelola hak akses

b. Mengelola data master

c. Mengelola data transaksi

d. Cetak kartu berobat

e. Cetak nomor pendaftaran

f. Cetak bukti pembayaran

g. Cetak surat pengantar rawat inap

h. Cetak surat keterangan sakit

i. Cetak surat keterangan sehat

j. Cetak surat rujukan

k. Cetak laporan master dan transaksi

Hasil dari perencanaan program, digambarkan dalam entity relationship diagram (ERD) pada Gambar 3.

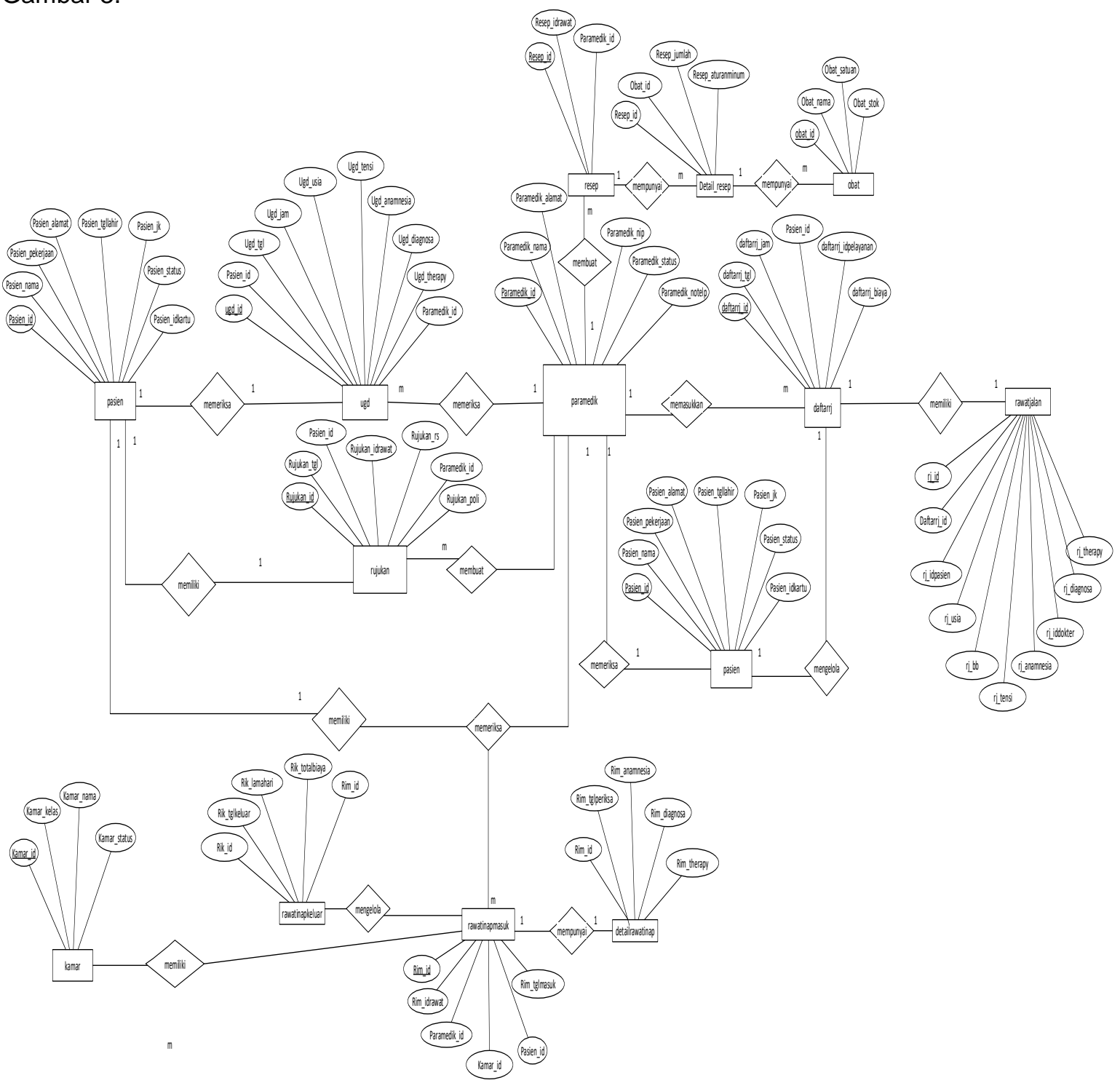

Gambar 3. Entity Relationship Diagram 
Seluruh item yang membentuk sebuah sistem komputer dan tools lainnya dan memungkinkan komputer agar mampu melaksanakan tugas yang diberikan. Dalam Gumawang (2010:3) disebutkan bahwa perangkat keras (hardware) adalah perangkat yang secara fisik dapat dilihat dan diraba, yang membentuk suatu kesatuan, sehingga dapat difungsikan. Klasifikasi perangkat keras untuk pemanfaatan sistem ini adalah sebagai berikut:
a. Monitor: 16"
b. Proccessor
:Pentium (R) IV $3.00 \mathrm{GHz}$
c. Memory $1 \mathrm{~GB}$ (Minimum)
d. Harddisk $80 \mathrm{~GB}$
e. Floppy disk : $3,5 "(1,44 \mathrm{MB})$
f. Keyboard : 108 Keys
g. Printer : Dot Matrix
h. Mouse : PS/2

Perangkat lunak yang dibutuhkan untuk menjalankan aplikasi program puskesmas ini adalah:

Sistem operasi $\quad$ : Microsoft Windows Xp x64 atau Windows $7 \times 6$

Bahasa Pemrograman : Microsoft Visual Basic 6.0

Program pendukung :-

Database : :MySQL

Perancangan selanjutnya diimplementasikan pada tampilan user interface yang dibutuhkan. Berikut beberapa user interface yang digunakan untuk menjalankan program.

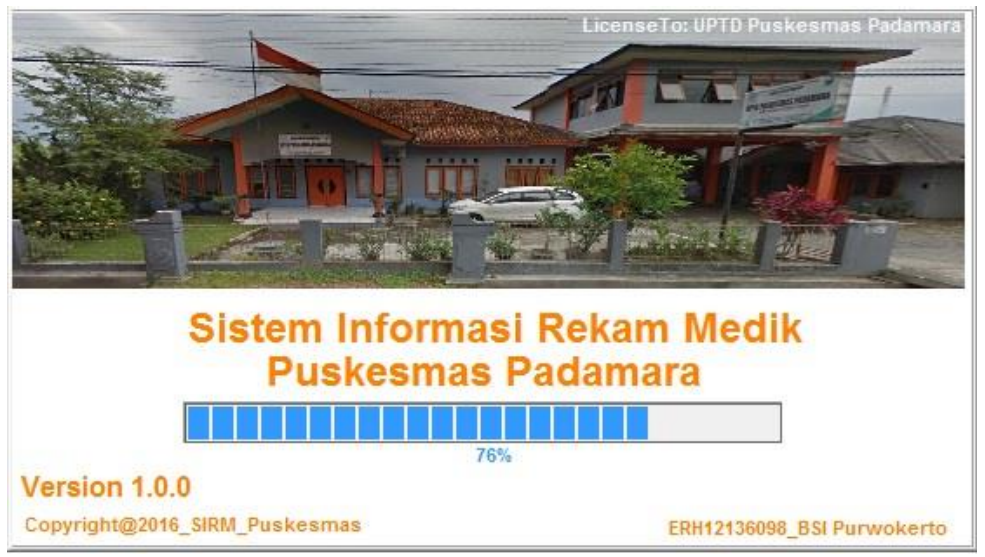

Gambar 5. Tampilan Form Splash

Form splash merupakan tampilan pembuka yang akan menerangkan tentang informasi dasar sistem informasi seperti nama aplikasi dan versinya.

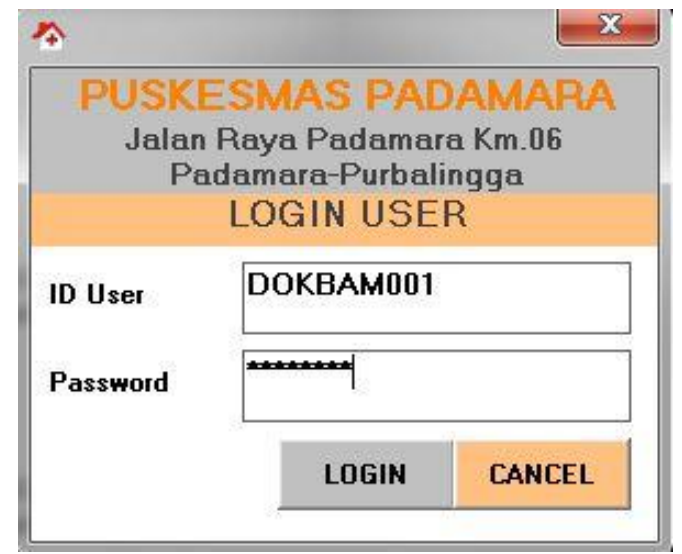

Gambar 6. Tampilan Form Login 
Sebelum user dapat menggunakan program, maka harus memasukan id user dan password. Login juga akan membuat hak akses dapat disesuaikan dengan masing-masing peran user. ID dan password telah diberikan sebelumnya oleh admin.

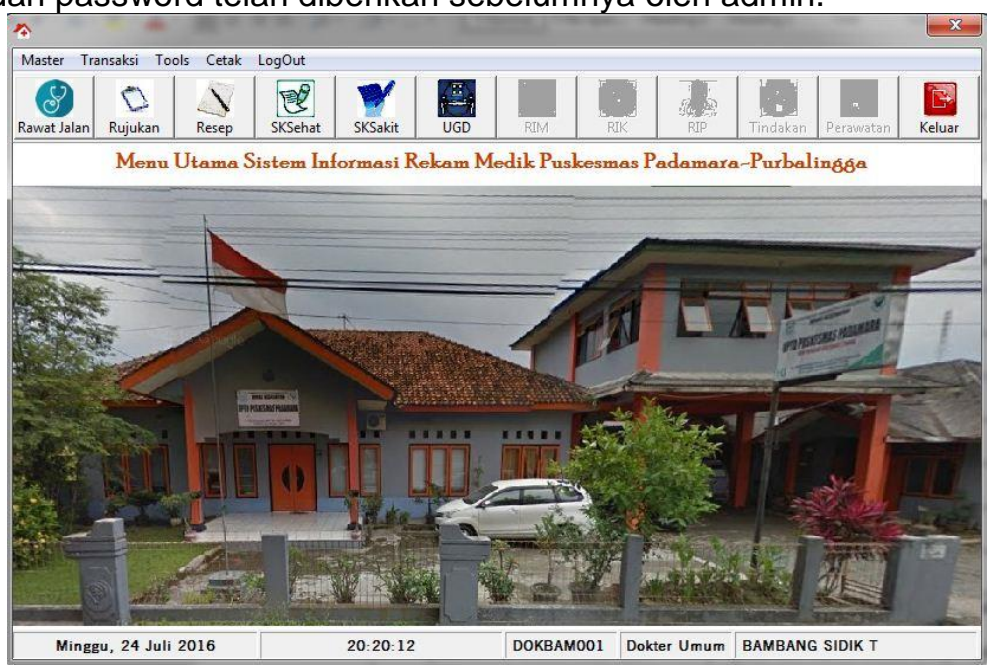

Gambar 7. Tampilan Form Menu Utama

Setelah login, user akan melihat form menu utama. Form ini menunjukan setiap menu yang dapat diakses oleh user. Pada bagian bawah,terdapat tanggal, waktu, user id, jabatan user, dan nama user yang sedang login.

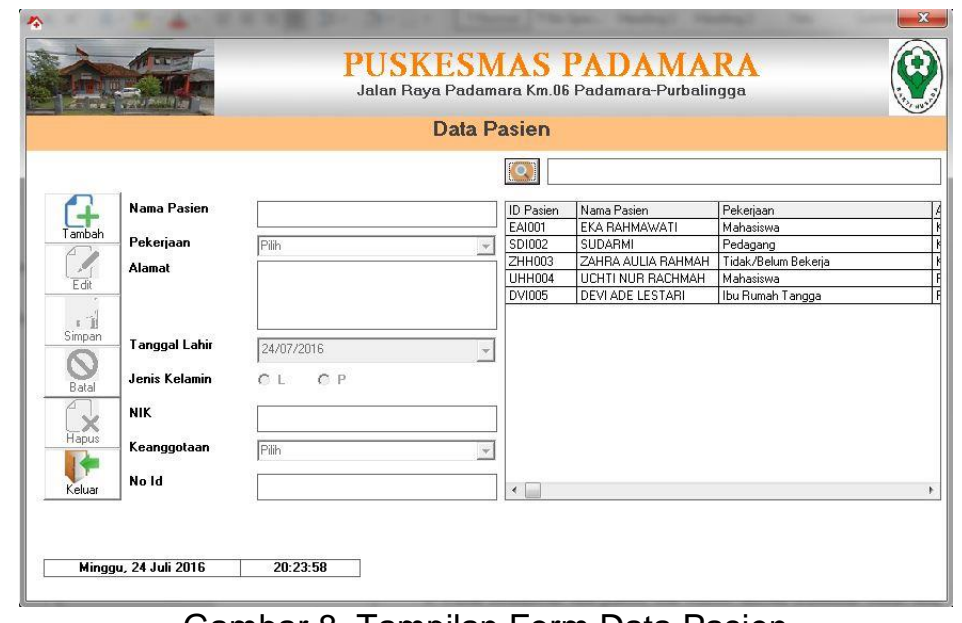

Gambar 8. Tampilan Form Data Pasien

Form data pasien merupakan salah satu form yang ada di sistem informasi rekam medis yang memiliki fungsi untuk menambah, menghapus, mengedit data pasien puskesmas. 


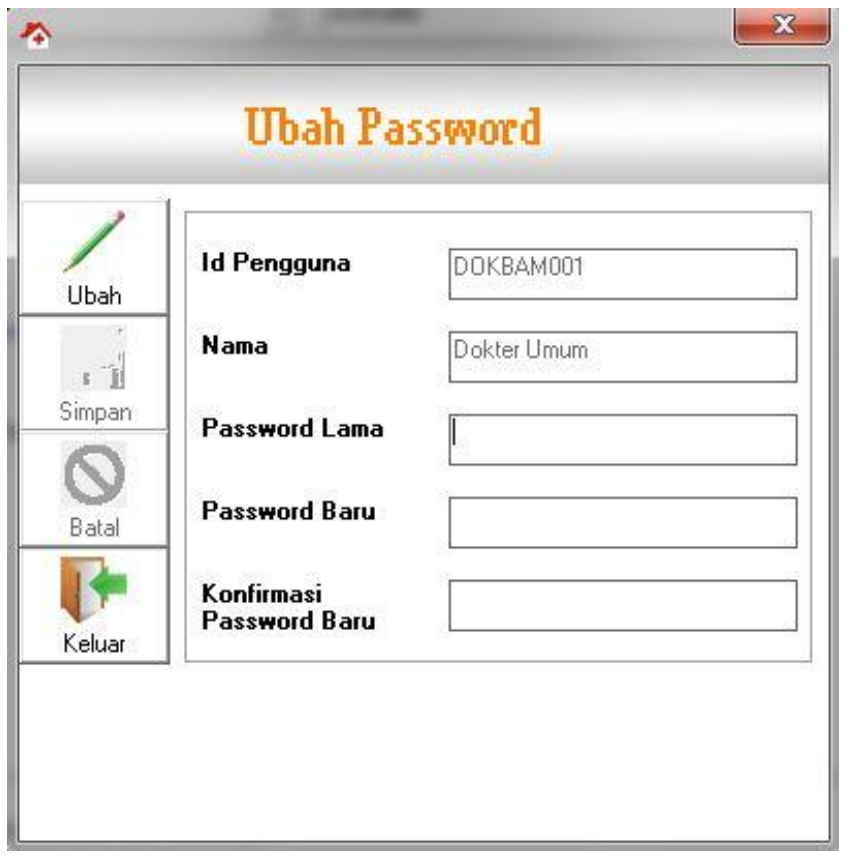

Gambar 9. Tampilan Form Ubah Password

Form ubah password merupakan salah satu form yang ada di sistem informasi rekam medis yang memiliki fungsi untuk mengubah password default dari setiap user yang memiliki hak akses ke sistem.

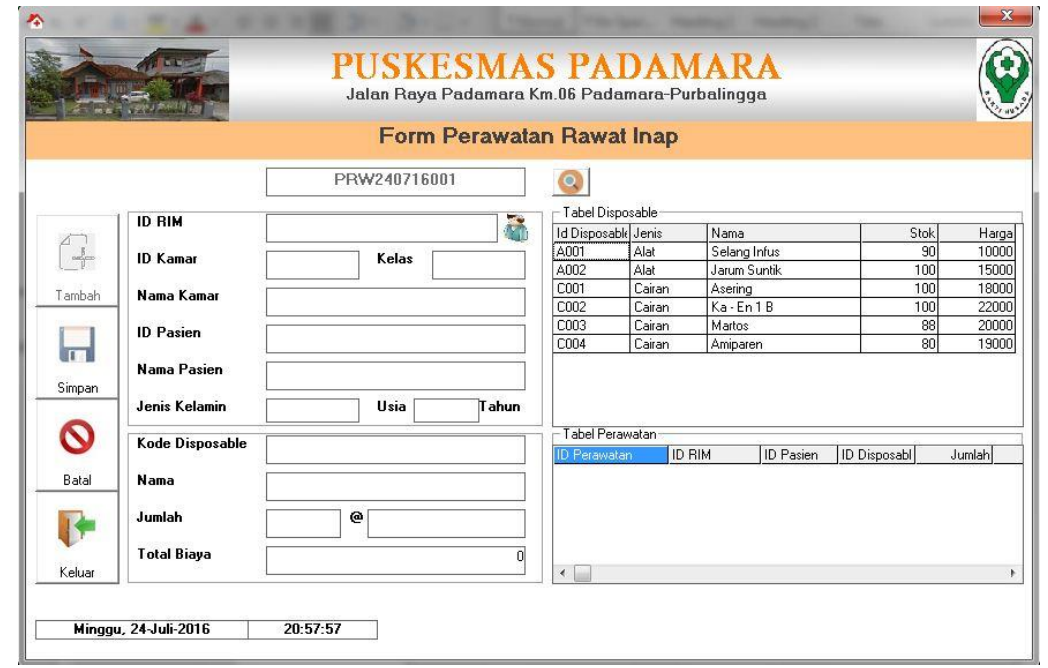

Gambar 10. Tampilan Form Perawatan

Form perawatan rawat inap merupakan salah satu form transaksi yang ada di sistem informasi rekam medis yang memiliki fungsi untuk mencatat perawatan pasien rawat inap di puskesmas.

\section{KESIMPULAN}

Bersasarkan pengamatan, prosedur rekam medik pada UPTD Puskesmas Padamara Purbalingga masih dilakukan secara manual. Dari pembahasan mengenai program rekam medik pada UPTD Puskesmas Padamara maka dapat diambil kesimpulan sebagai berikut: 
1. Penggunaan program rekam medik dapat mempercepat proses pengolahan data. Pengolahan data meliputi proses input data, penyimpanan data, pencarian data, pengubahan data dan penghapusan data.

2. Pencetakan kartu berobat dan riwayat penyakit pasien dapat dilakukan dengan mudah dan mengurangi resiko kesalahan penulisan. Untuk mendapatkan daftar riwayat penyakit tidak perlu mencari di dalam arsip.

3. Dengan menggunakan sistem yang terkomputerisasi dapat mengurangi kesalahankesalahan yang diakibatkan oleh manusia seperti redudansi dan kesalahan pencatatan.

4. Laporan transaksi maupun file master dapat diperoleh dengan mudah dan cepat, sehingga dapat meningkatkan kinerja. Laporan juga dapat dicetak kapan saja walaupun pelaporannya bulanan.

5. Data dapat diarsipkan dalam bentuk soft file dan cetak, sehingga mengurangi resiko hilang atau rusaknya data. Pengarsipan dalam bentuk soft file juga mempermudah pengguna dalam mencari data.

\section{REFERENSI}

Fathansyah. (2007). Basis Data. Bandung: Informatika.

Fatta, H. Al. (2007). Analisis \& Perancangan Sistem Informasi untuk Keunggulan Bersaing Perusahaan \& Organisasi Modern. In Analisis \& Perancangan Sistem Informasi untuk Keunggulan Bersaing Perusahaan \& Organisasi Modern (Vol. 53). Yogyakarta: Penerbit Andi.

Indonesia, M. K. R. (n.d.). Peraturan Menteri Kesehatan Republik Indonesia Tentang Keperawatan. https://doi.org/10.1017/CBO9781107415324.004

Kurniadi. (2008). Pemrograman Visual Basic. Retrieved from http://ci.nii.ac.jp/naid/110003738239/

Kusrini. (2010). Tuntunan Praktis Membangun Sistem Informasi Akuntansi dengan Visual Basic dan Microsoft SQL Server. Retrieved from https://books.google.com/books?id=NaKZXXsJdEC\&pgis $=1$

Madcoms. (2010). Mahir dalam 7 hari: Microsoft Visual Basic 6.0 +Crystal Report 2008.

Nuraida, I., \& S.E. (2008). Manajemen Administrasi Perkantoran. Retrieved from https://books.google.com/books?id=BqapYSJY_eYC\&pgis $=1$

Priyadi, Y. (2014). Kolaborasi SQL \& ERD dalam implementasi Database. Yogyakarta: Penerbit Andi.

S, R. A., \& Shalahuddin, M. (2004). Rekayasa Perangkat Lunak Terstruktur Dan Berorientasi Objek. Bandung: Informatika.

Simarmata, J. (2008). Perancangan Basis Data. In Penerbit Andi, Yogyakarta. Yogyakarta: CV Andi Ofset.

Suarga. (2012). Algoritma dan Pemrograman. https://doi.org/10.1017/CBO9781107415324.004

Sutarman. (2009). Pengantar Teknologi Informasi. Jakarta: PT Bumi Aksara.

Winarno, E., Ali, Z., \& SmittDev Community. (2013). Belajar Pemrograman VB6 dalam Sekejap. Jakarta: Elex Computindo. 